\title{
Ks. Robert Romuald Kufel, Archiwum parafialne w teorii i praktyce, Agencja Wydawnicza PDN, Zielona Góra 2021, ss. 124
}

Książka ks. Roberta Romualda Kufla pt. Archiwum parafialne w teorii i praktyce, którą przyszło mi recenzować, stanowi ważną pomoc dla księży proboszczów, wikariuszy oraz pracowników kancelarii parafialnych, którzy na co dzień stykają się z materiałami archiwalnymi i niejednokrotnie są kustoszami archiwów parafialnych. Zapewne do tej lektury, w której zostały zebrane fundamentalne zagadnienia z zakresu prawa, sięgną też pracownicy innych archiwów, chociażby zakonnych. W tym miejscu należy zaznaczyć, że autor recenzowanej pozycji jest doktorem habilitowanym, który to stopień uzyskał w 2011 r. na Papieskim Wydziale Nauk Historycznych we Wrocławiu, jest też wieloletnim dyrektorem Archiwum Diecezjalnego w Zielonej Górze z należytym wykształceniem archiwalnym (ukończył podyplomowe studia w zakresie archiwistyki na Wydziale Nauk Historycznych Uniwersytetu Mikołaja Kopernika w Toruniu), od 2016 r. pełni funkcję prezesa Zarządu Stowarzyszenia Archiwistów Kościelnych w Polsce.

W omawianej pozycji książkowej autor w dziesięciu rozdziałach dzieli się wiedzą m.in. na temat gromadzenia zasobu, ewidencjonowania, przechowywania, brakowania, zabezpieczania i udostępniania, jak również współpracy z archiwum diecezjalnym lub $\mathrm{z}$ archiwum prowincji zakonu i zgromadzenia zakonnego, a także podejmuje kwestię ochrony danych osobowych. Osoby sprawujące pieczę nad archiwaliami kościelnymi dzięki wiadomościom zawartym w tej pozycji książkowej będą mogły w sposób właściwy zadbać o powierzone im materiały zachować je dla przyszłych pokoleń, a jednocześnie stworzyć bazę do opracowania historii parafii, lokalnej społeczności czy konkretnych rodzin, co tym samym pomocne będzie w budowie drzewa genealogicznego.

Autor niniejszej publikacji swoje rozważania rozpoczął od wyjaśnienia pojęcia archiwum parafialnego, aby następnie ukazać cel realizowany przez archiwa i archiwistów oraz zadania wynikające z obowiązujących przepisów kancelaryjno-archiwalnych. Co z kolei pozwoliło przejść do ukazania znaczenia i roli archiwum.

Kolejny rozdział podnosi kwestię gromadzenia zasobu. Jak wynika z przedstawionych danych, i w tej kwestii nie ma jednolitych wytycznych, co ukazał 
autor, odwołując się do rozporządzeń synodów wybranych diecezji. Należy jednak stwierdzić, że dla duszpasterzy jest to nieoceniona podpowiedź dotycząca rodzaju gromadzonych materiałów archiwalnych. W tym rozdziale znajdziemy również wskazówki na temat przygotowania testamentu przez proboszcza oraz miejsca, w którym należy taki dokument przechowywać. Ważną informacją jest wiadomość, że w archiwum parafialnym znajdują się dokumenty wytworzone przez dziekana - o ile parafia ma taki charakter - i w konsekwencji także informacje o rodzaju materiałów wchodzących w skład archiwum dziekańskiego. Mowa jest też o zadaniach dziekana w odniesieniu do archiwów parafialnych oraz rocznych sprawozdaniach przygotowywanych dla kurii na temat stanu archiwum parafialnego oraz przechowywanych w nim dokumentów.

W kolejnym rozdziale zostało omówione ewidencjonowanie zasobu, prowadzenie księgi nabytków i ubytków, przygotowywanie spisów zdawczo-odbiorczych. Autor podnosi też kwestię kontroli archiwum parafialnego podczas wizytacji kanonicznej, powołując się na obowiązujące przepisy synodów w archidiecezji katowickiej czy diecezji gliwickiej.

Piąty rozdział omawianej pozycji przedstawia sposób przechowywania dokumentacji archiwalnej. Wskazuje, jak przygotować pomieszczenia, w których powinny być przechowywane dokumenty, jakie winny być warunki przechowywania materiałów archiwalnych w zakresie wentylacji pomieszczeń, odpowiedniej temperatury, oświetlenia, stosowania regałów, sposobów składowania akt czy zastosowania zabezpieczeń przed włamaniem i kradzieżą. Autor ukazał, że prowadzenie archiwum parafialnego jest obowiązkiem niełatwym, ale efekty, jakie przynosi porządkowanie i zabezpieczanie zasobu, dostarczą dużo satysfakcji.

W kolejnym rozdziale autor omawia kwestię brakowania akt, wskazuje na odpowiedzialność i świadomość, że zniszczonych akt nie da się już odtworzyć. W związku z tym proboszcz powinien kontaktować się $\mathrm{w}$ tej sprawie $\mathrm{z}$ archiwistą diecezjalnym. Wskazuje na podstawowe zadania, jak chociażby poznanie historii urzędu, zapoznanie się z kompetencjami i organizacją wewnętrzną urzędu oraz stosowanymi w nim przepisami kancelaryjno-archiwalnymi, sprawdzenie okresu przechowywania akt, ustalenie kategorii oraz spisanie akt, dla których minął okres przechowywania.

W rozdziale siódmym omawia sprawy związane z zabezpieczaniem materiałów archiwalnych, poczynając od form podstawowych, jak usunięcie metalowych elementów oraz plastikowych koszulek, przełożenie dokumentów z segregatorów i skoroszytów do bezkwasowych teczek. Omawia również rodzaje 
opakowań. Porusza sprawę cyfrowego zabezpieczania dokumentów przez digitalizację zbiorów.

W kolejnym rozdziale podejmuje sprawy związane $\mathrm{z}$ udostępnianiem materiałów archiwalnych $\mathrm{w}$ archiwum parafialnym, dzieli się praktycznymi wskazówkami, korzystając $\mathrm{z}$ wypracowanych norm w niektórych diecezjach, a zawartych $\mathrm{w}$ dokumentacji posynodalnej tychże diecezji.

Współpraca $\mathrm{z}$ archiwum diecezjalnym lub $\mathrm{z}$ archiwum prowincji zakonu i zgromadzenia zakonnego została omówiona w dziewiątym rozdziale. W tych kwestiach wskazuje na normy wypracowane przez Ośrodek Archiwów, Bibliotek i Muzeów Kościelnych przy Katolickim Uniwersytecie Lubelskim Jana Pawła II oraz na przepisy obowiązujące w niektórych diecezjach, mówiące o sprawowaniu nadzoru nad zasobami archiwów parafialnych przez archiwistów archiwów diecezjalnych czy prowincji zakonnej.

Ostatni, dziesiąty rozdział poświęcony jest ochronie danych osobowych, w którym to rozdziale autor opiera się na Praktycznych wskazaniach $z$ dnia 11 września 2020 r. dotyczących ochrony danych osobowych $w$ archiwach kościelnych wydanych przez Kościelnego Inspektora Ochrony Danych. Omawia zasady przetwarzania danych osobowych w kontekście materiałów archiwalnych, udostępniania materiałów archiwalnych zawierających dane osobowe, ingerencje w materiały archiwalne ze względu na przepisy o ochronie danych osobowych, środki techniczne i organizacyjne związane $z$ ochroną danych osobowych w archiwach oraz naruszenie ochrony danych osobowych.

Recenzowana pozycja została przez autora zaopatrzona w bogatą bibliografię, na którą składają się źródła i literatura związana z omawianym przedmiotem. Cenną pomocą dla archiwistów parafialnych jest też zamieszczony słownik niektórych terminów archiwalnych oraz aneks zawierający przykładową instrukcję o prowadzeniu kancelarii parafialnej w diecezji płockiej, przykładowy formularz księgi nabytków i ubytków, uproszczony spis zdawczo-odbiorczy czy protokół kontroli archiwum parafialnego $\mathrm{w}$ diecezji zielonogórsko-gorzowskiej.

Podsumowując, należy stwierdzić, że książka ks. Roberta Romualda Kufla jest wyrazem troski o tych, którzy są na pierwszej linii dbałości o zachowanie historycznego dziedzictwa Kościoła. Tym bardziej że archiwa i instytucje kościelne stanowią ważną część narodowego zasobu archiwalnego w Polsce. Autor w sposób czytelny przekazuje odbiorcom podstawowe informacje $\mathrm{z}$ dziedziny archiwistyki. Pozycja zawiera wiele cennych i praktycznych wskazówek, które pomogą osobom odpowiedzialnym za powierzony im zasób w prowadzeniu archiwum parafialnego czy zakonnego. Jak dotąd nie ma w Kościele katolickim - nie ma także w Kościele 
w Polsce - opracowanych jednolitych norm postępowania z materiałami archiwalnymi, jak również przepisów wspólnych dla wszystkich archiwów kościelnych. Owszem, w 2021 r. z ramienia Rady do spraw Kultury i Ochrony Dziedzictwa Kulturowego Konferencji Episkopatu Polski i Naczelnego Dyrektora Archiwów Państwowych został opracowany przez zespół ekspertów z archiwów państwowych i kościelnych dokument zatytułowany Postępowanie z materiałami archiwalnymi $w$ archiwach kościelnych wersja 1 . Katalog dobrych praktyk zawierający pewne wskazówki i zalecenia dotyczące postępowania z materiałami archiwalnymi w archiwach kościelnych. Wydaje się jednak, że wciąż ma on rys nadmiernie teoretyczny i zbyt ogólny. Tym ważniejsza staje się więc w przestrzeni archiwoznawczej i archiwalnej omawiana publikacja, gdyż jako rzetelny, merytoryczny punkt odniesienia ma szansę zająć miejsce nieformalnej normy dla właściwych działań w tym zakresie w tysiącach urzędów parafialnych.

S. Karolina Anna Kołodziejczyk CSFB 